\title{
MICROSTRUCTURE AND MECHANICAL PROPERTIES OF STRESS RELIEVED ELECTRON BEAM WELDED ALLOY 625
}

\section{B. Z. Hyatt and C. M. Brown}

\author{
Bettis Atomic Power Laboratory \\ Bechtel Bettis, Inc. \\ West Mifflin, PA. 15122
}

\begin{abstract}
The microstructure of electron beam (EB) welded alloy 625 plate was studied to assess the impact of various stress relief temperatures being considered. Moreover, the role of microstructural features on mechanical properties was studied. It was found that the microstructure of EB welded alloy 625 plate material is primarily cellular dendritic. The dendritic structure was shown through electron microprobe $\mathrm{x}$-ray analysis to be highly heterogeneous with respect to the elemental constituents and $\mathrm{Fe}$, $\mathrm{Ni}$, and $\mathrm{Cr}$ which were segregated in the dendrites. The alloying elements of $\mathrm{Nb}, \mathrm{Ti}$ and $\mathrm{Mo}$ were found to be enriched in the interdendritic spaces, the last regions to solidify, and the higher concentrations of these elements are believed to be responsible for enhanced delta-phase formation in these regions if the welds were stress relieved at moderate temperatures. Stress relief annealing for short times $\left(30-60\right.$ minutes) in the temperature range of $871^{\circ} \mathrm{C}\left[1600^{\circ} \mathrm{F}\right]$ to $982^{\circ} \mathrm{C}\left[1800^{\circ} \mathrm{F}\right]$ produced weld microstructures that consisted of predominantly delta phase "needles" $\left[\mathrm{Ni}_{3} \mathrm{Nb}\right]$ oriented in a Widmanstätten pattern as observed by SEM. The presence of delta phase adversely affected mechanical properties. Stress relief annealing at $1010^{\circ} \mathrm{C}\left[1850^{\circ} \mathrm{F}\right]$ for short times (45-60 minutes) produced a delta-free microstructure. The tensile and fracture toughness properties of weld and base material with and without delta phase were evaluated.
\end{abstract}

\section{INTRODUCTION}

A study was conducted to determine effective heat treatments for the fabrication of an alloy 625 part that would employ autogenous electron beam welding. Several factors needed to be considered in this work, to balance good mechanical properties in the final part's welded condition. Because of the known propensity for welded structures to develop high residual stresses, stress relief heat treatments had to be considered in the fabrication scheme to minimize or eliminate the potential for distortion. Distortion could occur upon final machining after welding, attributed to non-uniform relieving of weld residual stresses. Long term performance requirements, including structural stability and high fracture toughness, were also important considerations. Also, alloy 625 is recognized to be a complex metallurgical system, and the formation of embrittling phases such as the orthorhombic delta phase or carbide phases had to be considered, given that the material would be welded and then heat treated.

To accomplish the goal of establishing a robust heat treatment schedule for this welded material fabrication, a laboratory evaluation program was performed. The scope of work included the manufacturing of several weld mockups, the conducting of various heat treatments on wrought and welded alloy 625 materials, and performing microstructural and phase characterization, residual stress measurements, and mechanical property tests in various environments.

Through previous studies on the fracture toughness behavior of nickel based alloys, a significant degradation in cracking resistance in low temperature water was observed for alloy X750, alloy 690, and 600 and 690 type weld metals (EN82H and EN52, respectively). Therefore, the toughness of the welded and thermally treated alloy 625 material was tested in air and 
water to determine if the high fracture toughness of annealed alloy 625 was maintained in the low temperature water environment.

The objective of this work was to ensure that the strength and toughness of the weld was acceptable after heat treatment, and that the weld was adequately stress relieved to ensure dimensional stability throughout the fabrication and service life of a welded component.

\section{MATERIALS}

The material studied in this investigation was Inconel alloy 625 , having a nominal composition (weight percent) of $20 \% \mathrm{Cr}$, $4 \%$ $\mathrm{Fe}, 3.6 \% \mathrm{Nb}, 8.4 \% \mathrm{Mo} 0.3 \% \mathrm{Ti}, 0.27 \% \mathrm{Al}, 0.02 \% \mathrm{C}$, balance $\mathrm{Ni}$. Two heats were included in the program and detailed chemical analyses are shown in Table 1. The compositions reported in Table 1 were derived from certification data provided by the material vendor, from weld metal chemical analyses and electron microprobe analyses of the weld metal performed by Bechtel Bettis Inc. Initial EB weldment material consisted of a butt-welded "stepped-plate" which contained a 0.6 inch thick section on one end and a 2.6 inch thick section on the other end with a tapered transition section between ends. The primary alloy material was in the form of one-inch thick plates (the same heat of material as used for the fabrication of the "stepped-plate" as shown in Table 1). All of the test materials were mill annealed at $1600^{\circ} \mathrm{F}$ for one hour after hot rolling.

Welded plates were fabricated by making 1-inch thick butt joints using a full penetration continuous EB welding process. Figure 1 is a sketch of the process progression from the ingot stage through the final stress relief annealing of the EB welded plate material. It illustrates the total thermo-mechanical history of the materials evaluated, except for the "stepped-plate" material that was not homogenized prior to final hot working. The post-weld heat treatments $\left(1600^{\circ} \mathrm{F}-1850^{\circ} \mathrm{F}\right)$ were the subject of study of this work. Also noted in Figure 1 are the approximate precipitate phases that occurred during each of the processing steps.

\section{EXPERIMENTAL}

\section{Thermal Treatments}

Electron beam weldments of A625 plate were cut into convenient sections for heat treatment in a dynamic vacuum furnace. Heating rates $\left(150^{\circ} \mathrm{F} / \mathrm{hr}\right)$ and cooling rates $\left(80^{\circ} \mathrm{F} / \mathrm{hr}\right)$ to and from the stress relief annealing temperatures were specified and controlled to minimize distortion.

\section{Microstructural and Electron Microprobe Analyses}

Metallographic samples for light optical microscope (LOM) and scanning electron microscope (SEM) examinations were ground and polished using standard metallographic methods then etched with a $2 \%$ bromine-methanol solution. As part of etching, the surface was first activated in concentrated $\mathrm{HCl}$, rinsed in methanol, and subsequently etched in the bromine-methanol solution for two seconds followed by a methanol rinse.

Microstructural examinations for fine scale features were performed using a JEOL 6100 Scanning Microscope equipped with a $\mathrm{LaB}_{6}$ electron gun. SEM examinations were also conducted on broken mechanical property specimens to characterize the fractured surfaces.

A JEOL Model 8900 "Super Probe" electron microprobe x-ray analyzer was used to interrogate the polished metallographic EB weld specimen to identify segregation. Backscattered electron and $x$-ray images were recorded for the welded specimen. Moreover, qualitative and quantitative $x$-ray line intensity profiles were recorded by focusing the wavelength dispersive $x$-ray spectrometer on the elements of interest while scanning the specimen underneath the electron beam using a motorized stage stepped in increments of 0.5 micron and 1 micron, respectively.

\section{Stress Analyses}

Hole-drilling strain-gage techniques per ASTM E 837-95 were used to assess the residual weld stresses prior to and after stress relief annealing.

\section{Mechanical Property Tests}

The uniaxial round tensile specimens had a nominal diameter of $0.12 \mathrm{inch}$ and a gage length of 0.5 to 0.75 inch. Tensile tests were performed at room temperature in air using a servo-electric feedback-controlled system. The tests were performed per ASTM E8 with a stroke rate of $0.5 \mathrm{in} / \mathrm{hr}$.

\section{Environmental Fracture Toughness Tests}

Fracture toughness tests were performed on precracked compact tension (CT) specimens that had a width (W) of 1.2 inches and thickness (B) of 0.6 inch. The specimens had $20 \% \mathrm{v}$-shaped side grooves. Weld specimens were tested in the longitudinal orientation, with the notch parallel to the welding direction. Base metal specimens were tested in the L-T orientation as defined by ASTM E399. The tests were performed using ASTM E1820-99 as a guideline. Because of material size constraints, sufficiently large specimens could not be machined to meet the specification requirements. Therefore, $\mathrm{J}_{\mathrm{Q}}$ values are reported instead of $\mathrm{J}_{\mathrm{IC}}$ values. 
The fracture toughness tests were performed in air and water using servo-electric feedback-controlled systems that were operated in stroke control. A displacement rate of $0.050 \mathrm{inch} / \mathrm{hr}$ was used for the air tests and a slower displacement rate of $0.002 \mathrm{inch} / \mathrm{hr}$ was used in the water environment to allow sufficient time for environmental effects to occur.

Flowing autoclaves were used to conduct the environmental fracture toughness tests. The test environment was $130^{\circ} \mathrm{F}$ deaerated water buffered to room temperature $\mathrm{pH}$ between 10.0 to 10.4 .

For the air tests, clip gages were attached to the front face of the CT specimens to measure specimen displacement and this displacement was then converted to a load line value to calculate $J$ values. In the water environment, external linear variable differential transducers (LVDTs) were used to measure external displacement along the load train. The load train contribution to the measured displacement was determined by comparing the compliance-calculated slope of the load-displacement curve using compliance equations from Reference 1 and the actual slope. A factor was then obtained to multiply the overall displacement by to obtain an adjusted displacement corresponding to specimen compliance only. Test data was recorded digitally. The modified load and displacement data was than used to calculate $J$ values.

The fracture toughness tests were stopped once a target load drop or a target displacement value was reached. After completion of testing, each specimen was heat tinted for 20 minutes at $1000^{\circ} \mathrm{F}$ in an oven to mark the final crack length. The specimens were then fatigue cycled to failure at less than $50 \%$ of the final test load to reveal the fracture surface. A traveling microscope with digital position readout was used at $20 \mathrm{X}$ magnification to measure the beginning and final crack lengths on the fracture faces. A nine point overage crack length was calculated per ASTM E1820-99 procedures. R curves were calculated using the JNormalization technique given in Reference 2.

\section{RESULTS}

\section{Microstructure of EB Welded "Stepped Plate" Material}

Initial microstructural examinations were conducted on sections of the weldment from the thin ( 0.6 inch) and the thick ( 2.6 inch) ends of the "stepped plate", and the observations were identical. SEM micrographs showed the weld contained predominantly "needle-like" delta phase in a cellular dendritic structure (Figures $2 a$ and $2 b$ ), whereas the heat affected zones (HAZ) (Figure 2c) and the base metal (Figure 2d) exhibited lesser amounts of delta phase in equiaxed grain structures. In the vicinity of the delta plates or in the center of the grains are clusters of fine precipitates, judged to be gamma double prime $\left(\gamma^{\prime \prime}\right)$ in the weld, HAZ and base regions (see Figures $2 b, 2 c$, and $2 d$, respectively). LOM examinations (Figure 3 ) show that the base material exhibited a banded duplex grain structure with prominent globular intergranular carbides, delta phase at grain and twin boundaries, and fine matrix precipitates judged to be gamma double prime.

\section{Microstructural and Electron Microprobe Analysis of As-EB Welded Material}

EB welding of wrought A625 produces a cellular dendritic microstructure within directionally solidified columnar grains (Figures 4a,b). It is ntoed that niobium carbides appear as raised globular (white) precipitates within the dendritic stfucture (Figure 4b). Similar microstructural features were observed in backscattered electron images (sensitive to atomic number differences) (Figure 5a) and $x$-ray elemental images (Figures 5b-d) of the as-polished weld. These images show that the alloy elements in the weld are heterogeneously distributed. The $\mathrm{x}$-ray intensity images for $\mathrm{Nb}, \mathrm{Mo}$ and $\mathrm{Ti}$ are shown in Figures $5 \mathrm{~b}$-d, respectively, with the higher elemental concentrations appearing as the white to light gray regions. Although not shown, $\mathrm{Fe}, \mathrm{Cr}$ and $\mathrm{Ni}$ exhibited similar heterogeneous distributions. On the other hand, $\mathrm{x}$-ray images for $\mathrm{Al}, \mathrm{Cu}, \mathrm{Mn}$, and $\mathrm{Si}$, (not presented) suggested that that these elements were homogeneously distributed. $\mathrm{Al}, \mathrm{Cu}, \mathrm{Mn}$, and $\mathrm{Si}$ distributions were not determined because concentrations were below the $x$-ray imaging technique's limit of detection, which is estimated to be about 0.5 weight percent. Qualitative and quantitative x-ray intensity line profiles of the weld show that the concentrations of nickel, chromium, and iron vary inversely to the concentrations of niobium, molybdenum, and titanium. Data derived from the quantitative profiles were converted into quantitative estimates of the elemental concentrations shown in Table 1. The average composition is within the specification for the alloy 625 and is not significantly different from the manufacturer's certification analysis for the ingot.

The non-homogeneity of the alloying elements in the as-welded microstructure is consistent with prior work. Distinct elemental heterogeneity in Alloy 625 tungsten inert gas (TIG) weld metal and gas-tungsten-arc (GTA) weld metal were reported by F. Cortial, et.al. (Reference 3) and by M. J. Cieslak, et.al. (Reference 4), respectively.

\section{Microstructure and Residual Stress in the EB Weldment after a $1600^{\circ} \mathrm{F}$ Anneal}

Initial attempts at weld stress relief were performed at a relatively low temperature of $1600^{\circ} \mathrm{F}$ to be consistent with the final annealing temperature of the as received plate material. However, heat treatment at $1600^{\circ} \mathrm{F}$ resulted in delta-phase formation throughout the dendritic microstructure as shown in Figure 6a. At the higher magnification (Figure 6b), the delta phase is seen to be precipitated in plates in a Widmanstätten pattern. Intermittent fine and coarse (globular) carbides are also observed at cellular substructure grain boundaries. No delta phase precipitates were observed in the HAZ or in the base material (Figure 6c). 
Hole-drilling strain gage data for this weldment, obtained prior to and after the $1600^{\circ} \mathrm{F}$ thermal treatment, indicated that the fractional stress relaxation ${ }^{1}$ was approximately $95 \%$. Therefore, the $1600^{\circ} \mathrm{F}$ heat treatment was considered successful in regard to its ability to significantly reduce stresses.

\section{Microstructure After a Series of Heat Treatments to Eliminate Delta Phase}

Based on the observed formation of delta phase in the weldment material given a $1600^{\circ} \mathrm{F}$ heat treatment, a series of alternate thermal treatments were investigated. Using consistent heating and cooling rates, as-welded specimens were heat treated for 30 minutes at $1700^{\circ} \mathrm{F}, 1750^{\circ} \mathrm{F}, 1800^{\circ} \mathrm{F}$, and $1850^{\circ} \mathrm{F}$ to determine the effectiveness of a short exposure at high temperature in preventing delta phase formation. Figures $7 \mathrm{a}-\mathrm{c}$ and $8 \mathrm{a}, \mathrm{b}$ show that a diminishing amount of delta phase was formed upon heating, and after the $1850^{\circ} \mathrm{F}$ exposure, only small trace platelets were formed. A region of the $1850^{\circ} \mathrm{F}$ exposure sample, shown in Figure $8 \mathrm{~b}$ at high magnification, shows that micron-length delta phase needles are still present, and they intersect or are adjacent to globular carbide precipitates. Additional thermal treatments were then performed at $1800^{\circ} \mathrm{F}$ for 60 minutes, $1800^{\circ} \mathrm{F}$ for 90 minutes, $1850^{\circ} \mathrm{F}$ for 45 minutes, and $1850^{\circ} \mathrm{F}$ for 60 minutes in attempts to further homogenize the weld microstructure and more effectively prevent the formation of delta phase. Lesser amounts of delta phase formed with increased annealing times. While only a few remnant delta phase needles were observed after 45 minutes at $1850^{\circ} \mathrm{F}$, no delta phase was observed after 60 minutes at $1850^{\circ} \mathrm{F}$ (Figures 9a-d). Fractional stress relaxation of the welds was more than $80 \%$ after the $1850^{\circ} \mathrm{F}$ for 45 minutes stress relief treatment.

\section{Tensile Test Results}

Tensile tests were performed on composite specimens transverse to the weld, in the as-welded condition, and after various thermal treatments at temperatures ranging from $1700^{\circ} \mathrm{F}$ to $1850^{\circ} \mathrm{F}$ for times from 30 to 90 minutes. Table 2 provides the material property values. Post-weld heat treatments were seen to decrease the yield strength steadily from $80 \mathrm{ksi}$ for as-welded material to near $60 \mathrm{ksi}$ for material annealed at $1800^{\circ} \mathrm{F}$. Longer annealing times or higher temperatures did not result in lower yield strengths once a $60 \mathrm{ksi}$ minimum value was reached. This same trend was observed for tensile strength with the minimum value near $120 \mathrm{ksi}$. The percent reduction in area fluctuated between 55 and 65 , with no clear trend linked to temperature or time of anneal. The percent elongation value increased after annealing from $20 \%$ to almost $30 \%$ at temperatures at or above $1750^{\circ} \mathrm{F}$ with no clear dependence on annealing time. Based on this testing, the EB weld demonstrated good mechanical properties for stress relief temperatures between $1700^{\circ} \mathrm{F}$ and $1850^{\circ} \mathrm{F}$.

Additional tensile tests were performed with specimens machined parallel to the EB weld with the gage length located in the weld or completely in the base metal, for comparison purposes. Both as-welded material and material given a post weld $1600^{\circ} \mathrm{F}$ stress relief treatment for 2 hours were tested. The yield strength of the weld metal was lower than that of the base metal on both materials. Yield strengths increased after annealing for both base and weld metal. The increase was possibly due to the precipitation of the gamma double prime phase. The percent elongation of the weld metal was higher than that of the base material in both materials tested. The percent reduction in area values fluctuated but showed no consistent trends based on annealing temperature. The results of these tests showed the weld metal had the limiting yield strength.

\section{Fracture Toughness Test Results}

Fracture toughness tests were performed on as-welded and $1600^{\circ} \mathrm{F}$ annealed materials in room temperature air. The fracture toughness of both weld and base metal in the as-welded and $1600^{\circ} \mathrm{F}$ annealed condition was determined in $130^{\circ} \mathrm{F}$ deaerated water environment. Two heats of material were tested from separate material vendors. Table 3 provides the $J_{Q}$ fracture toughness value and tearing modulus as calculated using the J-Normalization technique from Reference 2 for the materials tested.

The as-welded Heat 1 Alloy $625 \mathrm{~EB}$ welded plate was tested in both air and water environments. Specimens from the base plate away from the welded area and specimens with the EB weld centered in the notch plane were both tested. The fracture toughness values are given in Table 3. The fracture toughness of the weld metal is lower than that of the base metal in both the air and water environment. The room temperature air $\mathrm{J}_{\mathrm{Q}}$ value of the base metal is $2700 \mathrm{in}-\mathrm{lb} / \mathrm{in}^{2}$ with a tearing modulus of 108 while the weld metal exhibits a fracture toughness of $1810 \mathrm{in}-\mathrm{lb} / \mathrm{in}^{2}$ with a tearing modulus of 98 . When the tests were performed in the water environment the $\mathrm{J}_{\mathrm{Q}}$ values were reduced to $869 \mathrm{in}-1 \mathrm{~b} / \mathrm{in}^{2}$ (tearing modulus of 29 ) for the base metal and $565 \mathrm{in}-\mathrm{lb} / \mathrm{in}^{2}$ (tearing modulus of 23 ) for the weld metal. The water caused approximately a $70 \%$ reduction in fracture toughness (both the $J_{Q}$ and tearing modulus values) of both the base and weld metal.

Both heats of Alloy 625 plate were EB welded and stress relief annealed at $1600^{\circ} \mathrm{F}$ for 2 hours. Compact tension specimens were machined from both the weld and base metal then tested in air and water environments. The fracture toughness results are provided in Table 3. The R curves are plotted in Figure 10. The fracture toughness performance of the $1600^{\circ} \mathrm{F}$ annealed Heat 1 material was lower than that of the as-welded material. The $\mathrm{J}_{\mathrm{Q}}$ value in air for the base metal is $2036 \mathrm{in}-\mathrm{lb} / \mathrm{in}^{2}$ with a tearing modulus of 86 and for the weld metal is $1021 \mathrm{in}-\mathrm{lb} / \mathrm{in}^{2}$ with a tearing modulus of 92 . The base metal $\mathrm{J}_{\mathrm{Q}}$ value is twice that of the weld metal. The performance in water was degraded from the air properties. The $J_{Q}$ value in water for the base metal is

\footnotetext{
${ }^{1}$ Fractional Stress Relaxation $=\left(1-\sigma_{f} / \sigma_{0}\right) \times 100 \%$
} where $\sigma_{f}=$ final stress, after post-weld thermal treatment and $\sigma_{0}=$ initial stress, after welding but prior to post-weld thermal treatment. 
$693 \mathrm{in}-\mathrm{lb} / \mathrm{in}^{2}$ with a tearing modulus of 26 and the weld metal has a value of $526 \mathrm{in}-\mathrm{lb} / \mathrm{in}^{2}$ with a tearing modulus of 17. Although the base metal $J_{\mathrm{Q}}$ was much higher in air, the difference is much less in the water environment.

The fracture surfaces of the base metal in air and water and the weld metal in air showed the typical dimpled appearance of a ductile material as illustrated in Figure 11a. Fractography of the weld metal in water revealed that fracture occurred along delta phase boundaries in the weld metal tested in water (Figure 11b).

The fracture toughness of the second heat was lower than that of the first heat of EB welded Alloy 625 annealed at $1600^{\circ} \mathrm{F}$. The $\mathrm{J}_{\mathrm{Q}}$ value of the base metal in air was $1574 \mathrm{in}-\mathrm{lb} / \mathrm{in}^{2}$ (tearing modulus of 53) and the weld metal was $823 \mathrm{in}-\mathrm{lb} / \mathrm{in}^{2}$ (tearing modulus of 58). The water environment caused a decrease in fracture toughness as expected. The $\mathrm{J}_{\mathrm{Q}}$ was 665 in-lb/in ${ }^{2}$ (tearing modulus of 32) for the base metal and $\mathrm{J}_{\mathrm{Q}}$ of $331 \mathrm{in}-\mathrm{lb} / \mathrm{in}^{2}$ (tearing modulus of 10) for the weld metal. The low tearing modulus value indicates that the weld metal was susceptible to low temperature water rapid cracking. The shape of the load-displacement curve approached the $\mathrm{K}_{\mathrm{IC}}$ (linear elastic) analyses conditions (as defined in ASTM 1820-99) with very little displacement after maximum load was reached. The critical stress intensity factor at maximum load, $\mathrm{K}_{\mathrm{Pmax}}$, for the weld metal in water is approximately $100 \mathrm{ksi}$ in.

The base metal fracture toughness was greater than that of the weld metal in both the as received and $1600^{\circ} \mathrm{F}$ annealed condition (more than doubled) in both test environments. Heat 1 fracture toughness was greater than the Heat 2 fracture toughness after the $1600^{\circ} \mathrm{F}$ anneal in both the base and weld metal in both test environments. Some of this decrease can be attributed to the difference in yield strength of the weld and base metal and between the heats of material. However, in the water environment the second heat of weld metal appears to be more susceptible to environmental degradation than the first heat of weld metal.

\section{DISCUSSION}

The experiments performed on EB welded plate materials have shown that the kinetics of delta phase precipitation are related directly to elemental segregation most probably due to that of niobium. Although no new time-temperature-transformation (TTT) diagrams were developed, previously published Alloy 625 TTT diagrams of Floreen (Reference 5) as well as previous Alloy 625 investigations (References 3-7) were useful in interpreting the observed microstructural results for the Alloy 625 EB weldments. Delta phase was first observed in the current study of the EB weld material formed in wrought material that exhibited severe banding (alternate regions of fine grains separated by coarse grains, shown in longitudinal directions) with the fine grain boundaries pinned by niobium carbides. The segregation of niobium in the bands in the form of niobium carbides as well as the presence of $\gamma^{\prime \prime}\left(\mathrm{Ni}_{3} \mathrm{Nb}\right.$ ) contributed to the acceleration of delta phase precipitate formation in the weld and the HAZ, even though melting should have dissolved these precipitates. Moreover, in the case of the EB welds formed in non-banded primary material, electron microprobe studies identified elemental segregation (primarily niobium, molybdenum, and titanium in the interdendritic spaces) which occurred during weld solidification. This segregation was judged instrumental in the formation of delta phase in the weld and the $\mathrm{HAZ}$ subjected to stress relief heat treatment for times of two hours at $1600^{\circ} \mathrm{F}$. As reported by Floreen (Reference 5) for Alloy 625 TIG welds, the kinetics of delta phase precipitation were altered, decreasing the time for precipitation of delta phase to approximately one hour at $1600^{\circ} \mathrm{F}$. Furthermore, several thermal treatment studies of EB weldments at $1600^{\circ} \mathrm{F}$ performed by the authors also confirm this observation. These initiation times for delta phase precipitation in weld metal were reduced approximately by a factor of 50 in comparison to the delta start times in wrought material at the same temperature. Current electron microprobe studies of the as received EB weldment (see Table 1) showed a concentration maximum of $\sim 9 \mathrm{wt} . \% \mathrm{Nb}$ in the weld compared to the bulk level of $3.9 \mathrm{wt}$. \%. This enhanced $\mathrm{Nb}$ concentration in the weld supports the decreased time to initiate delta phase precipitation. Delta phase precipitates contained $\sim 25 \mathrm{wt}$. $\% \mathrm{Nb}$, as shown by Cortial et.al. (Reference 3) through analyses of extractions from TIG welds in Alloy 625. Therefore, to eliminate weld segregation and to prevent delta phase formation, higher temperature homogenization treatments were investigated. Thermal treatment of the weldment at $1850^{\circ} \mathrm{F}$ for at least 45 minutes was shown to homogenize the weld preventing delta phase formation, while maintaining a high weld tensile strength and substantially lowering the weld's residual stresses. The microstructural sensitivity was also evident in the low fracture toughness for the Alloy 625 weld metal heat treated at $1600^{\circ} \mathrm{F}$ for 2 hours and tested in a water environment. The low fracture toughness of the weld in water, in comparison to that of the base metal, was attributed to the onset of transgranular cracking along delta phase platelets. Previous tests on nickel based alloys (summarized in Reference 8) classifies the cracking resistance of these materials and would classify the $1600^{\circ} \mathrm{F}$ post-weld thermally treated EB weld metal as a moderate to low crack resistant material. Therefore, elastic-plastic fracture mechanics methods for fracture control are likely needed when using the thermally treated EB welded material in a water environment.

\section{SUMMARY}

Annealing experiments performed on EB welded alloy 625 were designed to promote weld stress relief and to minimize welded part distortion after final machining. A $1600^{\circ} \mathrm{F} 2$ hour annealing treatment provided for adequate weld stress relief, however, this treatment promoted the formation of delta phase in the weld which in turn significantly reduced its fracture toughness in $130^{\circ} \mathrm{F}$ water. Through a series of annealing treatments from $1700^{\circ} \mathrm{F}$ to $1850^{\circ} \mathrm{F}$ aimed to provide stress relief as well as to prevent the formation of delta phase, a final annealing treatment at $1850^{\circ} \mathrm{F}$ for 45 minutes was selected for alloy 625 weldments. This thermal treatment provided weld homogenization, stress relaxation, as well as adequate strength, and the microstructure was devoid of delta phase. 


\section{ACKNOWLEDGEMENTS}

The authors gratefully acknowledge the stress measurement analyses performed by W. Kroenke, the electron microprobe analysis performed by F. W. Page, the review of microstructural examinations performed by M. G. Burke, and for the critical review of this document by P. N. Pica and W. C. Porr.

\section{REFERENCES}

1. Saxena, A. and Hudak, Jr., S. J., "Review and extension of compliance information for common crack growth specimens", INTERNATIONAL JOURNAL OF FRACTURE, Vol. 14, No. 5, October 1978, p.453-468.

2. Porr, W. C. and Mills, W. J., "Application of the Normalization Data Analysis Technique for Single Specimen R-Curve Determination", Bettis Atomic Power Laboratory, Report, B-T-3269, February 1999.

3. Cortial, F., Corrieu, J. M., and Vernot-Loier, C., "Influence of Heat Treatments on Microstructure, Mechanical Properties, and Corrosion Resistance of Weld Alloy 625", Superalloys 718, 625, 706 and Various Derivatives, TMS 1994, p. 859.

4. Cieslak, M.J., Headley, T.J., Kollie, T., and Romig, A.D. Jr., "A Melting and Solidification Study of Alloy 625", Met. Trans. A Vol.19A, September 1988, p. 2319.

5. Floreen, S., Fuchs, G. E., and Yang, W.J. "The Metallurgy of Alloy 625”, Superalloys 718, 625, 706 and Various Derivatives, TMS 1994, p.13.

6. Vernot-Loier, C. and Cortial, F., "Influence of Heat Treatments on Microstructure, Mechanical Properties and Corrosion Behavior of Alloy 625 Forged Rod", Superalloys 718, 625, 706 and Various Derivatives, TMS 1991, p. 409.

7. Kohler, M., "Effect of the Elevated-Temperature Precipitation in Alloy 625 on Properties and Microstructure", Superalloys 718, 625, 706 and Various Derivatives, TMS 1991, p. 363

8. Mills, W. J. and Brown, C. M., "Fracture Behavior of Nickel-Based Alloys in Water," Ninth International Conference on Environmental Degradation of Materials in Nuclear Power Systems-Water Reactors, TMS 1999, pp. 167-177.

\begin{tabular}{|c|c|c|c|c|c|c|}
\hline \multicolumn{7}{|c|}{ Table 1 - Chemical Composition (percent by weight) } \\
\hline & \multicolumn{4}{|c|}{ Heat 1} & \multicolumn{2}{|c|}{ Heat 2} \\
\hline Element & Cert & Weld & $\begin{array}{l}\text { Weld Microprobe } \\
\text { range }\end{array}$ & $\begin{array}{l}\text { Weld Microprobe } \\
\text { mean }\end{array}$ & Cert & Weld \\
\hline $\mathrm{Ni}$ & 62.8 & 61.6 & $56.3-63.6$ & 61.2 & 61.33 & 61.4 \\
\hline $\mathrm{Cr}$ & 20.5 & 21.0 & $20.3-22.2$ & 21.7 & 21.82 & 21.8 \\
\hline Mo & 8.4 & 9.0 & $7.4-10.5$ & 8.5 & 9.00 & 9.0 \\
\hline $\mathrm{Fe}$ & 4.07 & 4.2 & $3.5-4.4$ & 4.1 & 3.56 & 3.7 \\
\hline $\mathrm{Nb}+\mathrm{Ta}$ & 3.63 & 3.5 & $2.0-8.7$ & 3.9 & 3.54 & 3.5 \\
\hline $\mathrm{Ta}$ & .02 & $<0.10$ & NM & $\mathrm{NM}$ & $<0.01$ & $<0.10$ \\
\hline $\mathrm{C}$ & .024 & 0.027 & $\mathrm{NM}$ & NM & 0.019 & 0.0244 \\
\hline $\mathrm{Mn}$ & .02 & 0.02 & $0.04-0.08$ & 0.05 & 0.04 & 0.04 \\
\hline $\mathrm{Cu}$ & .05 & $<0.05$ & $0.03-0.08$ & 0.05 & 0.04 & $<0.05$ \\
\hline $\mathrm{Si}$ & $<.01$ & $<0.1$ & $0.01-0.05$ & 0.03 & 0.08 & $<0.1$ \\
\hline $\mathrm{Co}$ & .02 & 0.01 & $0.00-0.04$ & 0.01 & 0.05 & 0.04 \\
\hline$S$ & $<.0003$ & 0.0004 & NM & NM & 0.001 & 0.0003 \\
\hline$P$ & .005 & $<0.005$ & $\mathrm{NM}$ & $\mathrm{NM}$ & 0.006 & $<0.005$ \\
\hline $\mathrm{Al}$ & .27 & 0.23 & $0.12-0.26$ & 0.19 & 0.25 & 0.23 \\
\hline $\mathrm{Ti}$ & .31 & 0.34 & $00.25-0.49$ & 0,35 & 0.26 & 0.27 \\
\hline B & .003 & 0.0025 & NM & NM & 0.002 & $<0.002$ \\
\hline $\mathrm{Mg}$ & .0015 & 0.002 & NM & $\mathrm{NM}$ & 0.002 & 0.002 \\
\hline
\end{tabular}




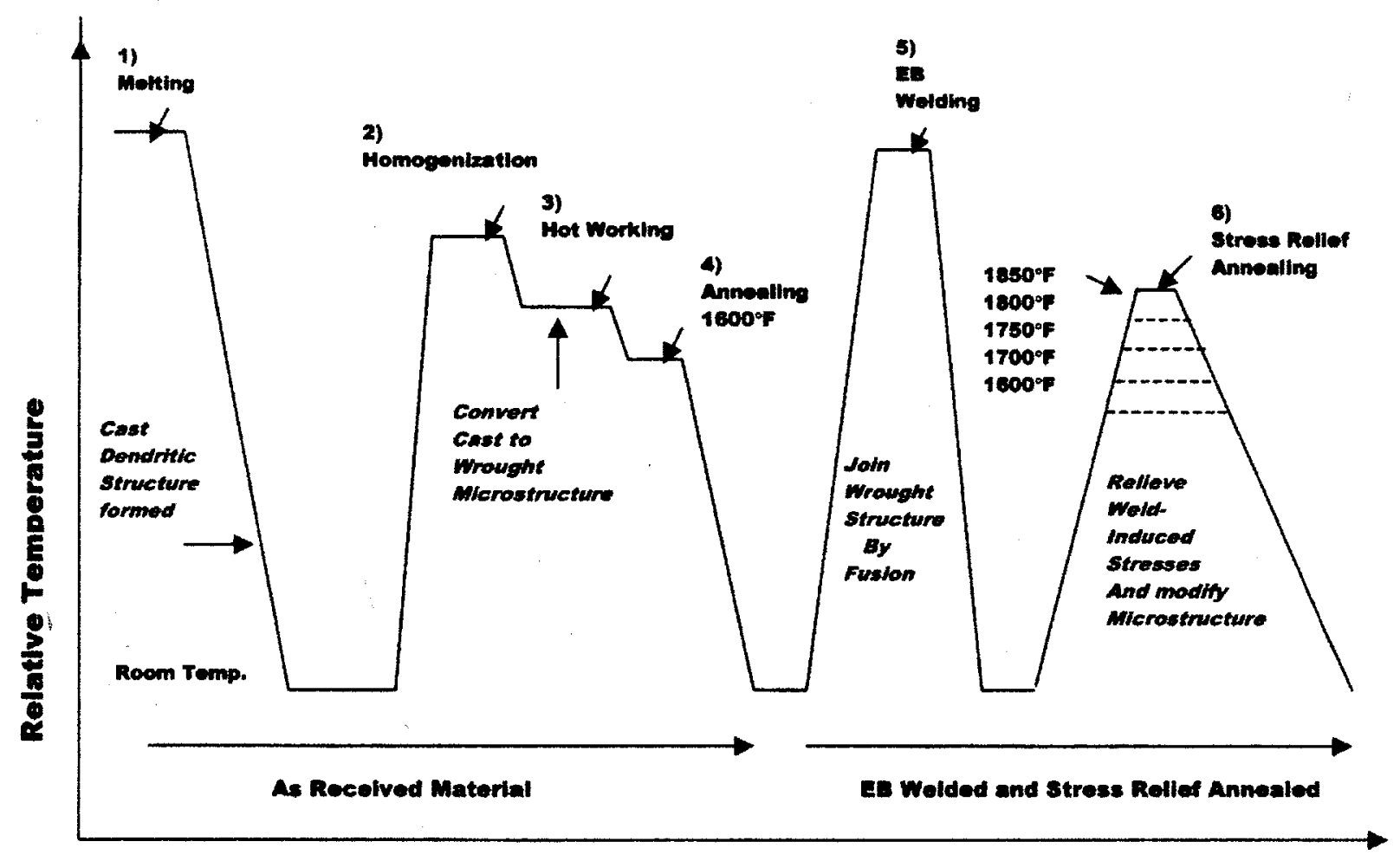

Process Progression

1) Melting: Composition is established in the liquid state. The extent of melting and liquid handling control establishes inclusion content and distribution; then upon solidification, inclusions, $\mathrm{NbC}$ and Laves phase, other carbides, and carbonitrides are formed. A dendritic microstructure with Laves and delta phases is created.

2) Homogenization: Most Laves phase, delta phase, carbides $\left(\mathrm{M}_{23} \mathrm{C}_{6}, \mathrm{M}_{6} \mathrm{C}\right)$ and smaller $\mathrm{NbC}$ particles are dissolved.

3) Hot working: $\mathrm{M}_{23} \mathrm{C}_{6}$ carbides, should dissolve. Dendritic microstructure is replaced with a wrought austenitic microstructure.

4) Annealing at $1600^{\circ} \mathrm{F}$ for one hour: Carbides such as $\mathrm{M}_{6} \mathrm{C}$ may form. Laves phase and $\mathrm{NbC}$ not previously dissolved during homogenization may also be present. On cooling to room temperature, $\mathrm{M}_{23} \mathrm{C}_{6}$ will form; therefore, Laves phase, $\mathrm{NbC}, \mathrm{M}_{23} \mathrm{C}_{6}$, and $\mathrm{M}_{6} \mathrm{C}$ may be present.

5) EB Welding: Almost all of the precipitates in the fusion zone should be dissolved. Then upon solidification, $\mathrm{NbC}$, Laves phase and carbides may precipitate. In the HAZ grain growth will occur, and carbides will also precipitate and decorate grain boundaries.

6) Stress Relief Annealing at $1850^{\circ} \mathrm{F}$ for 45 minutes should dissolve some $\mathrm{M}_{23} \mathrm{C}_{6}$; however, these carbides as well as $\mathrm{M}_{6} \mathrm{C}$ should again reform on cooling to room temperature.

Figure 1. Process Progression from Ingot Melting of Alloy 625 through Stress Relief Annealing of EB Welded Plate Material. 
a)

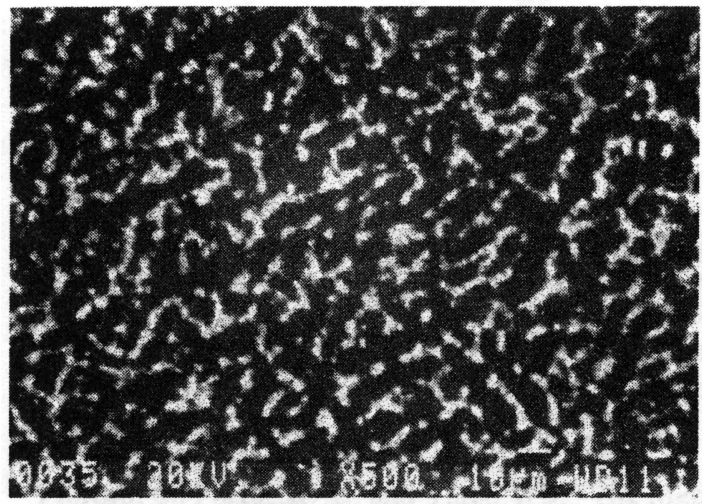

c)

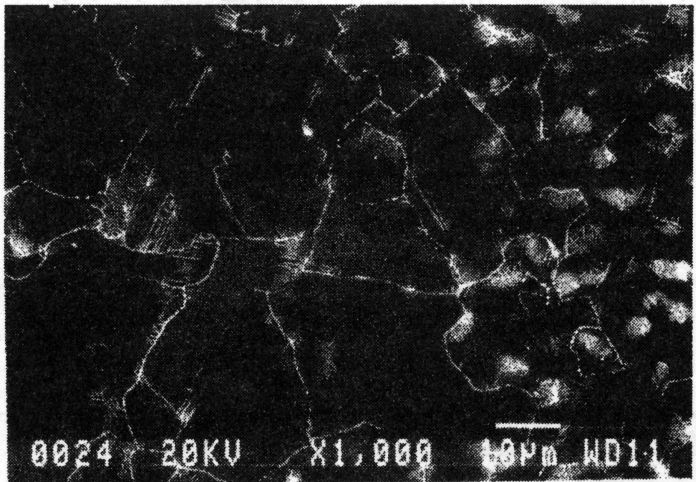

b)

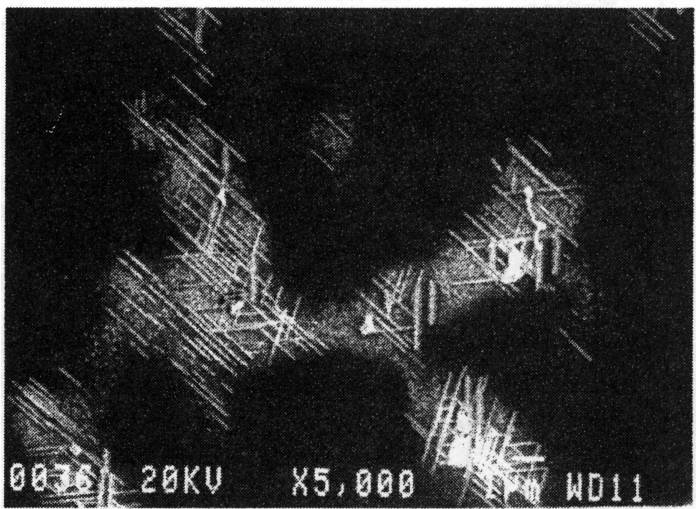

d)

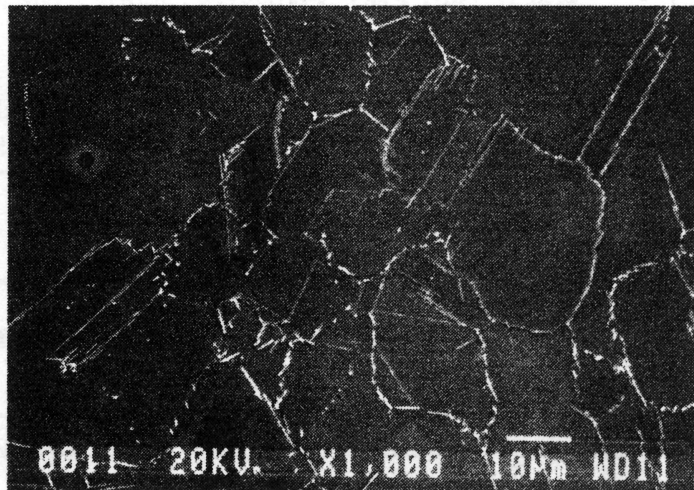

Figure 2 - SEM Micrographs of as-EB welded Alloy 625 stepped plate weld, HAZ and base metal. Note in a) the cellular dendritic equiaxed grain structure of the weld, b) the interdendritic region of the weld showing predominantly delta phase needles, c) the recrystallized equiaxed structure of the $\mathrm{HAZ}$ with regions of delta phase observed adjacent to grain boundary needles, and d) the recrystallized equiaxed grain structure with delta phase clustered about the grain boundaries in the base metal.

a)

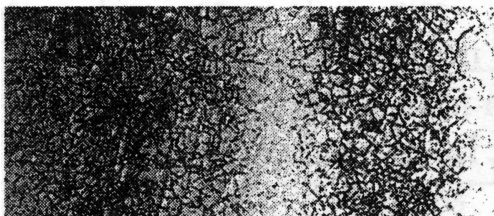

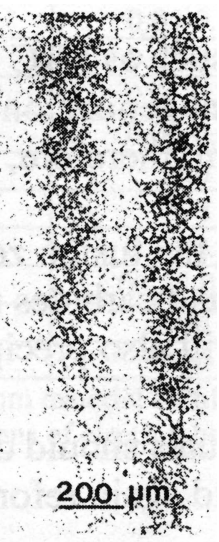

b)

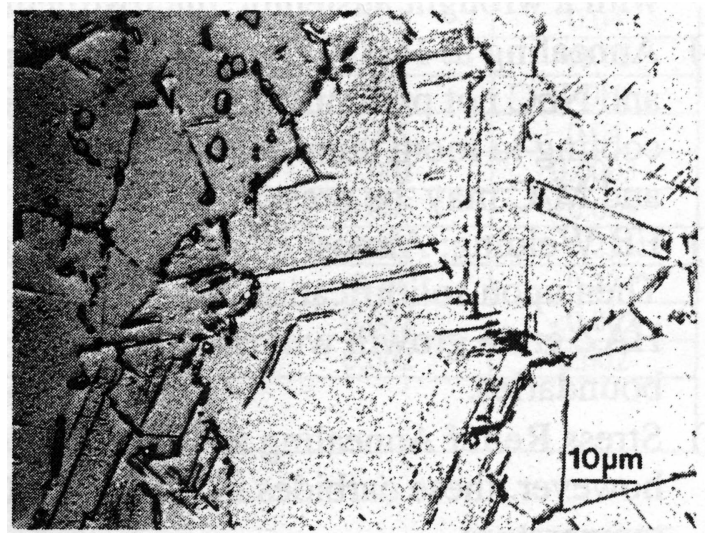

Figure 3 - LOM of the base material of the EB welded alloy 625 stepped plate material. a) shows a dark etching banded duplex grain microstructure with regions of segregated carbides and b) shows delta phase needles at grain and twin boundaries. Note also, dark etching globular intragranular carbides and faint etching of fine matrix precipitates judged to be gamma double prime. [orthophosphoric, electrolytic etch] 
a)

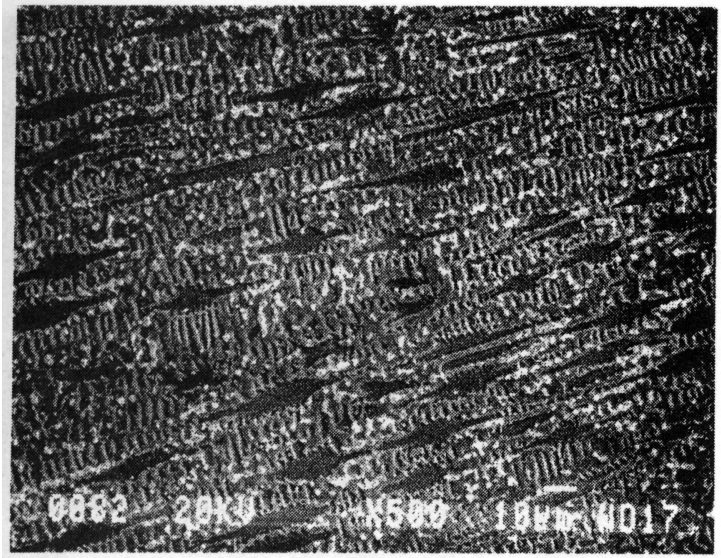

b)

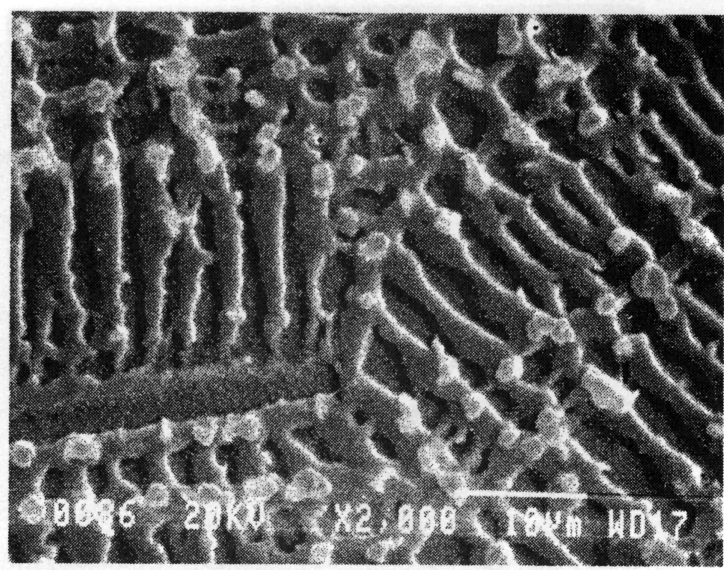

Figure 4 - SEM micrographs of the as EB welded material: a) 500X and b) 2000X show cellular dendritic columnar grain microstructure. Niobium carbides appear as raised (white) globular precipitates. [bromine-methanol etch]

a)

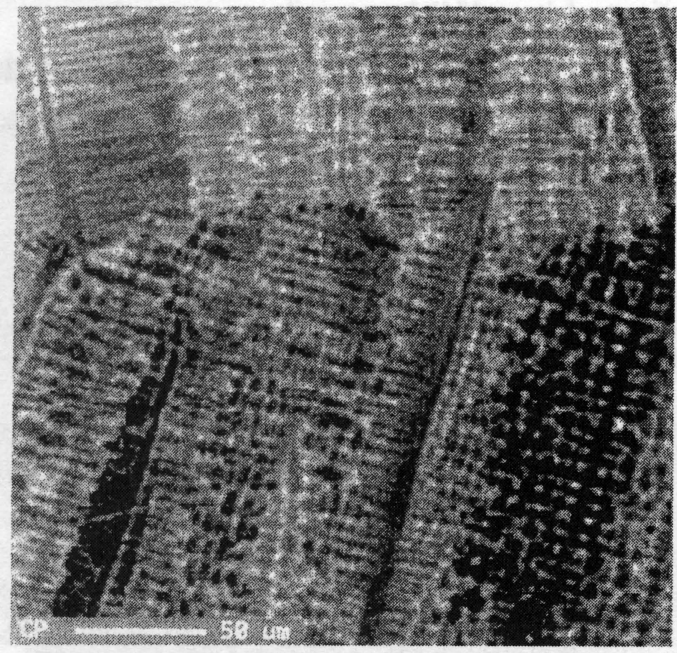

c)

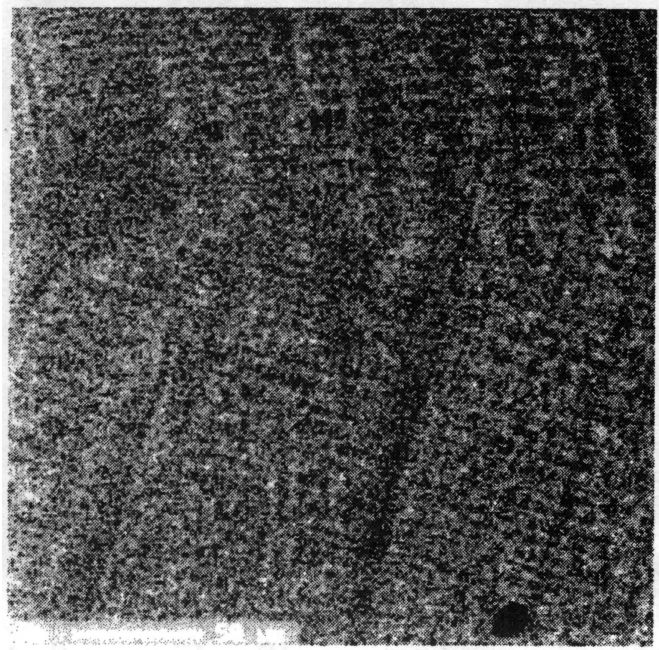

b)

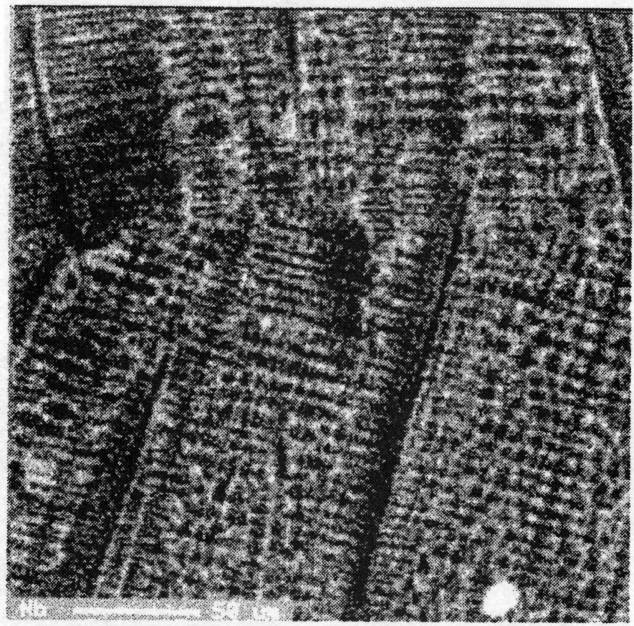

d)

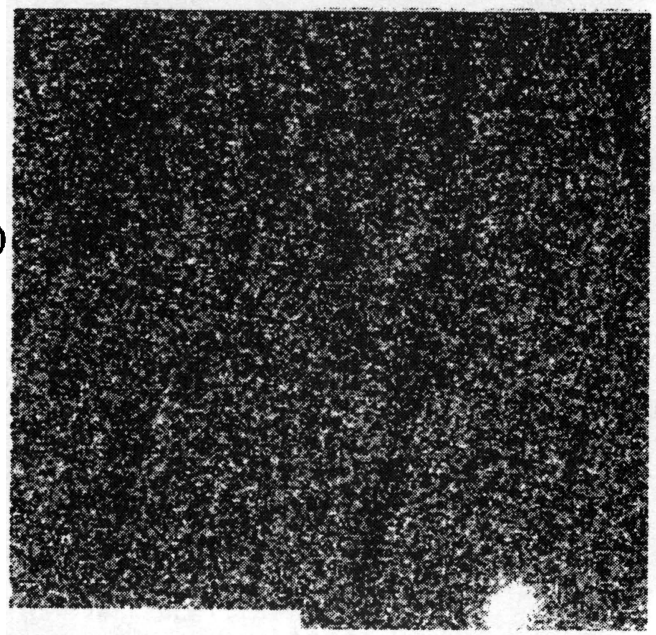

Figure 5-Backscattered and X-ray elemental images of the as EB welded material: a) backscattered electron image and b) $\mathrm{Nb}, \mathrm{c}$ ) $\mathrm{Mo}$, d) $\mathrm{Ti}$ x-ray elemental images show elemental segregation. 
a)

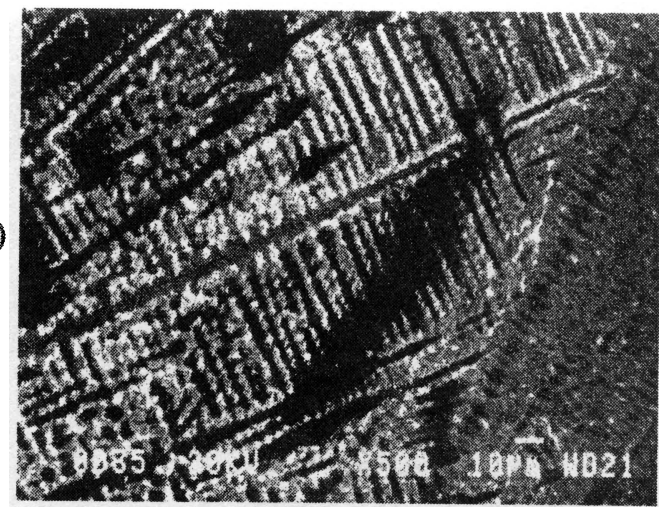

c)

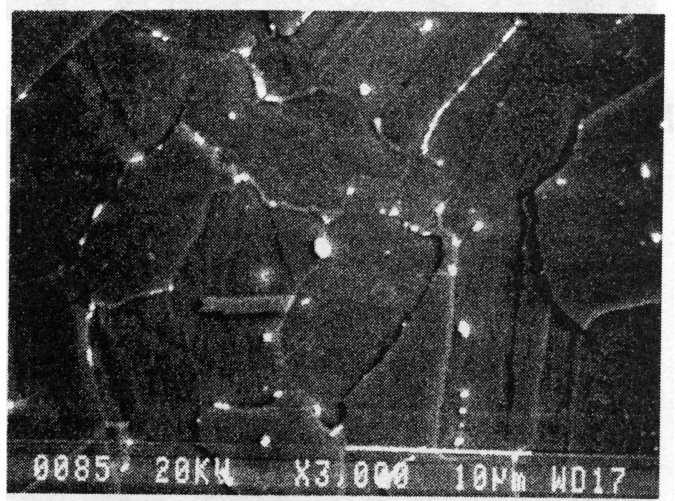

b)

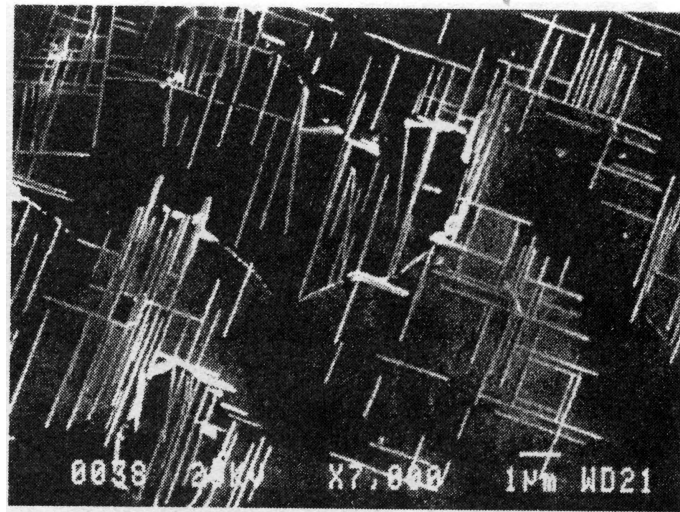

Figure 6-SEM micrographs of the EB weld after a $1600^{\circ} \mathrm{F}$ anneal for two hours: a) weld shows predominantly delta phase in a region of columnar dendrites, b) at the higher magnification, the delta phase plates precipitated in a Widmanstätten pattern. Intermittent fine and coarse (globular) carbides are also observed at cellular substructural grain boundaries, c) shows the equiaxed grain structure of the base metal with grain boundaries as well as some twin boundaries intermittently decorated with carbides. Coarse intragranular carbides are also observed.

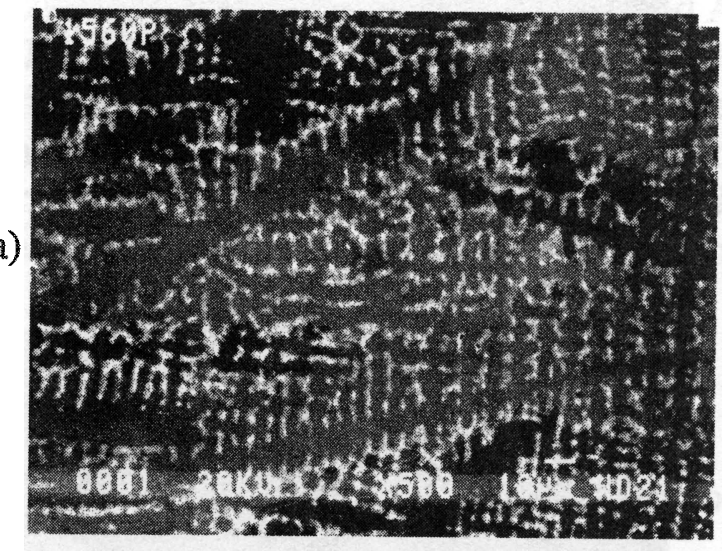

b)

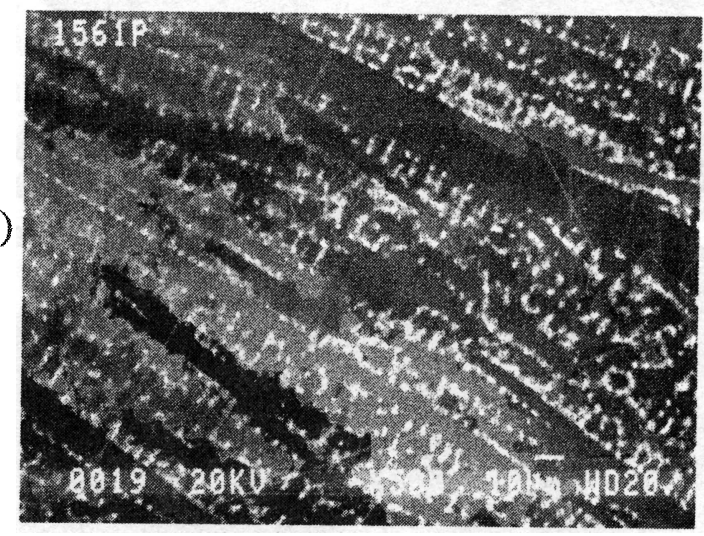

Figure 7 - SEM micrographs of EB weld specimens heat treated for 30 minutes at a) $1700^{\circ} \mathrm{F}$, b) $1750^{\circ} \mathrm{F}$, and c) $1800^{\circ} \mathrm{F}$. A diminishing amount of delta phase was observed upon heating. (See Figures 8a,b also). 
a)

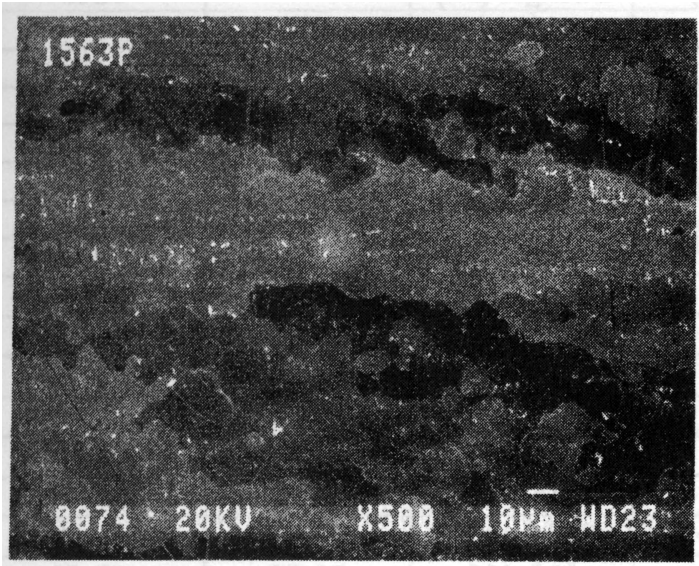

b)

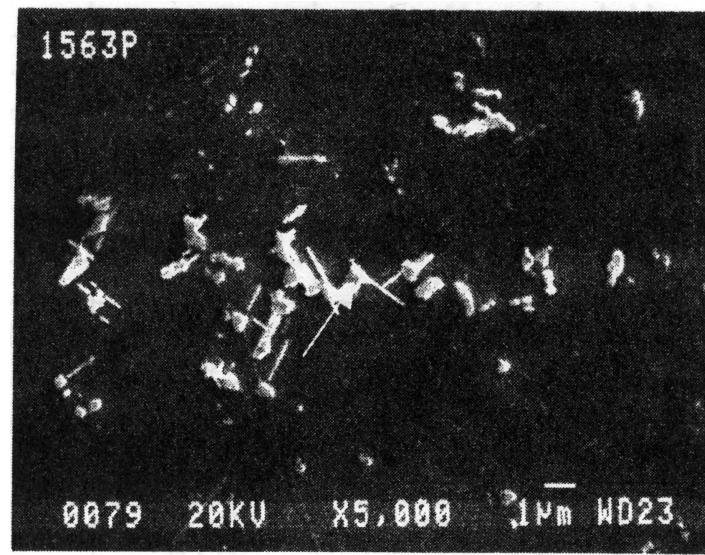

Figure 8 - SEM micrographs of EB weld specimens heat treated for 30 minutes at $1850^{\circ} \mathrm{F}$. a) only small remnants of delta were observed and b) high magnification SEM micrograph of a typical region shows small micron-length delta phase needles are prominent (See arrow). These delta phase needles intersect or are adjacent to globular carbide precipitates.

a)

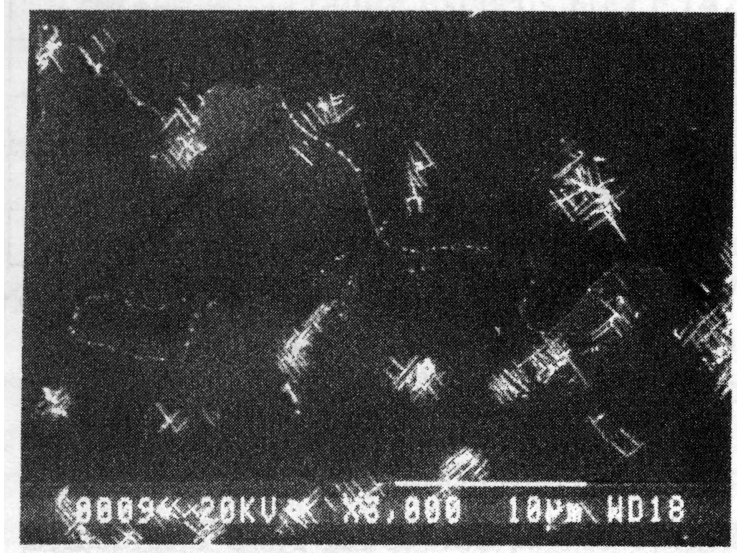

c)

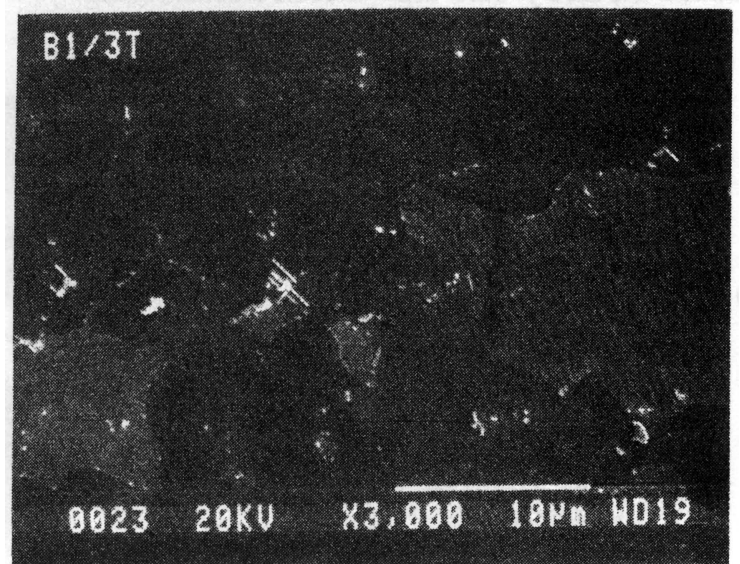

b)

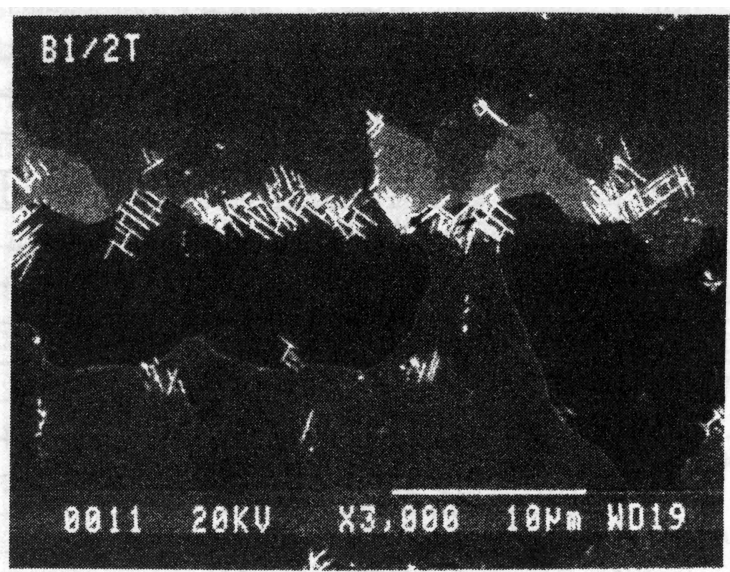

d)

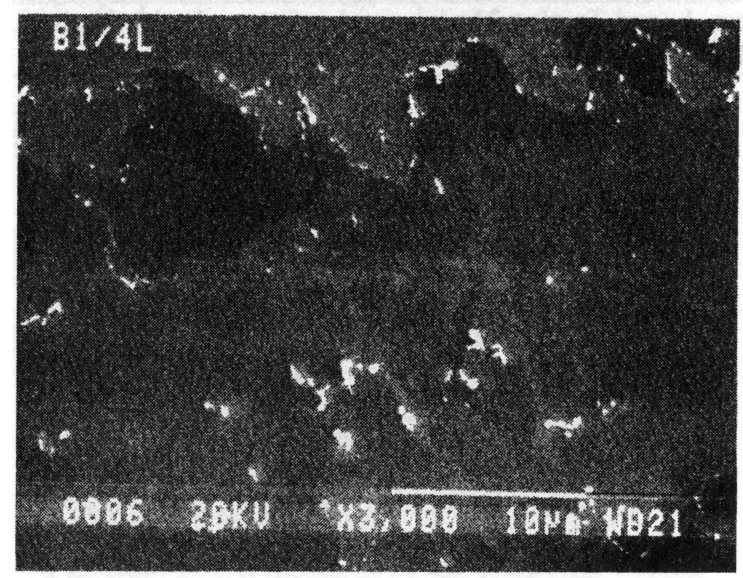

Figure 9 - SEM Micrographs of Annealed EB Weldments of Alloy 625. a) $1800^{\circ} \mathrm{F}, 60$ minutes, delta phase observed, b) $1800^{\circ} \mathrm{F}, 90$ minutes, delta phase observed, c) $1850^{\circ} \mathrm{F}, 45$ minutes, only a few remnant delta phase "needles" observed, d) $1850^{\circ} \mathrm{F}, 60$ minutes, no delta phase observed (primarily Niobium Carbides are noted.) 
Table 2 - Mechanical Properties of EB Welded Alloy 625 Plates in Room Temperature Air

\begin{tabular}{|c|c|c|c|c|c|c|}
\hline $\begin{array}{l}\text { Thermal } \\
\text { Treatment }\end{array}$ & $\begin{array}{c}\text { Material } \\
\text { Source }\end{array}$ & $\begin{array}{c}\text { Base or Weld } \\
\text { Metal }\end{array}$ & $\begin{array}{l}0.2 \% \text { Offset Yield } \\
\text { Strength (ksi) }\end{array}$ & $\begin{array}{c}\text { Tensile } \\
\text { Strength (ksi) }\end{array}$ & \%Elongation & $\begin{array}{c}\text { \%Reduction in } \\
\text { Area }\end{array}$ \\
\hline \multirow[t]{3}{*}{ As-welded } & \multirow[t]{3}{*}{ Heat 1} & Base & 99 & 156 & 38 & 57 \\
\hline & & Weld & 74 & 131 & 48 & 61 \\
\hline & & Weld* & 78,80 & 125,125 & 18,20 & 63,64 \\
\hline \multirow[t]{4}{*}{$1600^{\circ} \mathrm{F}, 2 \mathrm{~h}$} & \multirow[t]{2}{*}{ Heat 1} & Base & 118 & 166 & 35 & 56 \\
\hline & & Weld & 84 & 145 & 42 & 49 \\
\hline & \multirow[t]{2}{*}{ Heat 2} & Base & 95 & 148 & 39 & 44 \\
\hline & & Weld & 78 & 138 & 39 & 49 \\
\hline $1700^{\circ} \mathrm{F}, 30 \mathrm{~m}$ & Heat 1 & Weld* & 76,76 & 129,130 & 23,21 & 62,51 \\
\hline $1750^{\circ} \mathrm{F}, 30 \mathrm{~m}$ & Heat 1 & Weld* & 63,64 & 127,127 & 32,32 & 61,55 \\
\hline $1800^{\circ} \mathrm{F}, 30 \mathrm{~m}$ & Heat 1 & Weld* & 59,63 & 120,121 & 31,29 & 67,61 \\
\hline $1800^{\circ} \mathrm{F}, 60 \mathrm{~m}$ & Heat 1 & Weld* & 63,63 & 118,119 & 34,35 & 68,68 \\
\hline $1800^{\circ} \mathrm{F}, 90 \mathrm{~m}$ & Heat 1 & Weld* & 63,63 & 117,119 & 33,36 & 61,64 \\
\hline $1850^{\circ} \mathrm{F}, 30 \mathrm{~m}$ & Heat 1 & Weld* & 61,62 & 115,116 & 28,28 & 65,68 \\
\hline $1850^{\circ} \mathrm{F}, 45 \mathrm{~m}$ & Heat 1 & Weld* & 63,66 & 116,117 & 32,36 & 67,68 \\
\hline $1850^{\circ} \mathrm{F}, 60 \mathrm{~m}$ & Heat 1 & Weld* & 61,63 & 115,115 & 34,36 & 63,70 \\
\hline
\end{tabular}

\begin{tabular}{|c|c|c|c|c|}
\hline \multicolumn{5}{|c|}{$\begin{array}{l}\text { Table } 3 \text { - Fracture Toughness Properties of EB Welded } \\
\text { Alloy } 625 \text { Plates }\end{array}$} \\
\hline $\begin{array}{l}\text { Heat } \\
\text { Treatment }\end{array}$ & $\begin{array}{c}\text { Material } \\
\text { Source }\end{array}$ & $\begin{array}{l}\text { Base or } \\
\text { Weld } \\
\text { Metal }\end{array}$ & $\begin{array}{l}\mathrm{J}_{\mathrm{Q}}(\text { in- } \\
\left.\mathrm{lbs} / \mathrm{in}^{2}\right)\end{array}$ & $\begin{array}{l}\text { Tearing } \\
\text { Modulus }\end{array}$ \\
\hline \multicolumn{5}{|c|}{ Room Temperature Air Results } \\
\hline \multirow[t]{2}{*}{ As-welded } & \multirow[t]{2}{*}{ Heat 1} & Base & 2700 & 108 \\
\hline & & Weld & 1810 & 98 \\
\hline \multirow{4}{*}{$\begin{array}{c}1600^{\circ} \mathrm{F} \\
2 \mathrm{~h}\end{array}$} & \multirow[t]{2}{*}{ Heat 1} & Base & 2036 & 86 \\
\hline & & Weld & 1021 & 92 \\
\hline & \multirow[t]{2}{*}{ Heat 2} & Base & 1574 & 53 \\
\hline & & Weld & 823 & 58 \\
\hline \multicolumn{5}{|c|}{$130^{\circ} \mathrm{F}$ Water Results } \\
\hline \multirow[t]{2}{*}{ As-welded } & \multirow[t]{2}{*}{ Heat 1} & Base & 869 & 29 \\
\hline & & Weld & 565 & 23 \\
\hline \multirow{4}{*}{$\begin{array}{c}1600^{\circ} \mathrm{F} \\
2 \mathrm{~h}\end{array}$} & \multirow[t]{2}{*}{ Heat 1} & Base & 693 & 26 \\
\hline & & Weld & 526 & 17 \\
\hline & \multirow[t]{2}{*}{ Heat 2} & Base & 665 & 32 \\
\hline & & Weld & 331 & 10 \\
\hline
\end{tabular}

Notes: $\mathrm{J}_{\mathrm{Q}}$ and Tearing Modulus values were obtained using the $\mathrm{J}$ - Normalization Technique (Reference 3). $\mathrm{h}=$ hours

a)

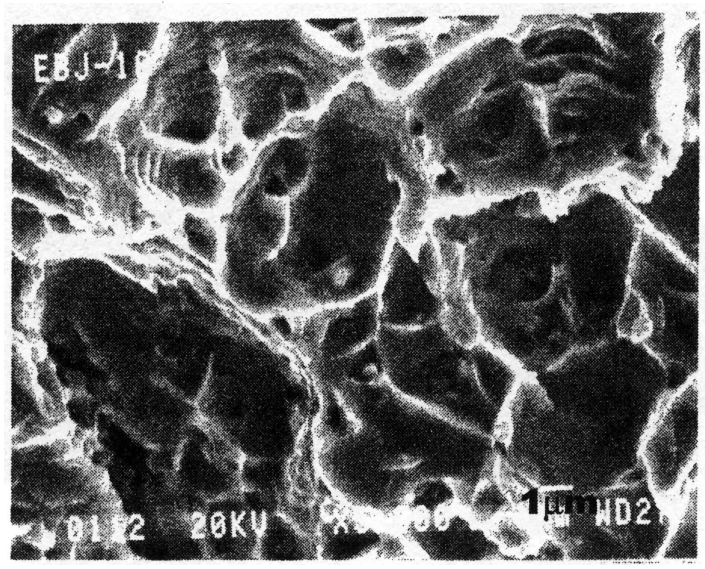

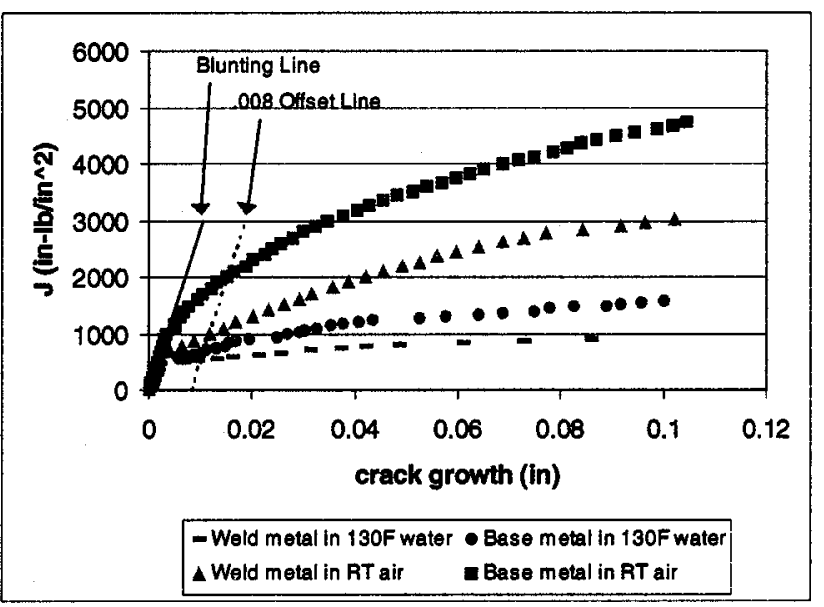

Figure 10 - R Curves for $1600^{\circ} \mathrm{F}$ annealed Heat 1 Alloy 625 EB welded material.

b)

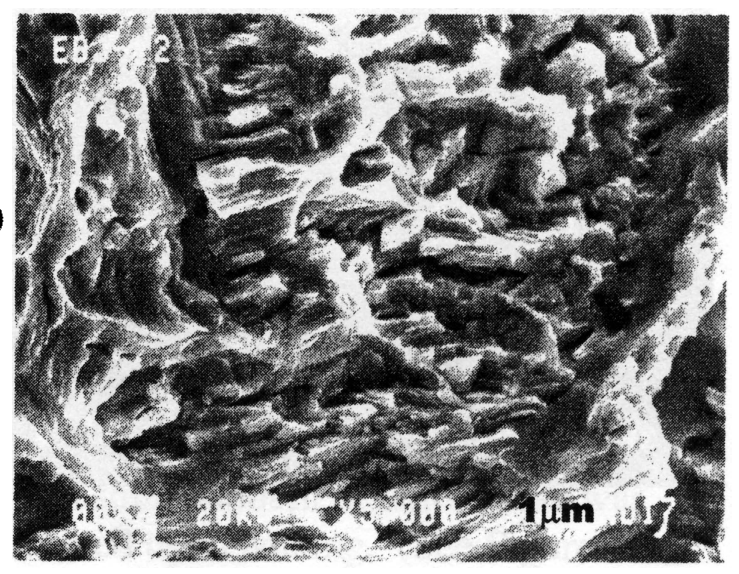

Figure 11 - SEM fractographs of $1600^{\circ} \mathrm{F}$ annealed EB welded Alloy 625 fracture toughness specimens tested in $130^{\circ} \mathrm{F}$ water: a) base metal exhibits dimple rupture with carbide particles in the center of the dimples, and $b$ ) weld metal fracture surface exhibited cracking along delta phase interfaces. 